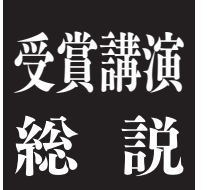

\title{
受容体作動性 $\mathrm{Ca}^{2+}$ 流入機構の分子メカニズム - $\alpha_{1 \mathrm{~A}}$ アドレナリン受容体と Snapin の相互作用による増大を中心に
}

鈴木 史子

要約 : $\alpha_{1 \mathrm{~A}}$ アドレナリン受容体（以下 $\alpha_{1 \mathrm{~A}}$ 受容体） を含む $\mathrm{Gq}$ タンパク共役型受容体の活性化は, 細胞内 $\mathrm{Ca}^{2+}$ ストアからの一過性の $\mathrm{Ca}^{2+}$ 遊離と, それに続く持 続的な $\mathrm{Ca}^{2+}$ 流入を惹起する. 平滑筋組織においては, この持続的な $\mathrm{Ca}^{2+}$ 流入が収縮反応を調節する主要な 因子となっていることが知られており, 創薬の点から も注目されている。しかし，この受容体の活性化によ る $\mathrm{Ca}^{2+}$ 流入機構の詳細は, 未だ完全には明らかにさ れていない。私たちは, $\mathrm{Gq}$ タンパク共役型受容体の 一つとして $\alpha_{1 \mathrm{~A}}$ 受容体に着目し，この受容体の活性 化により惹起される $\mathrm{Ca}^{2+}$ 流入機構の解明を目的とし て研究を行なった。 その結果, Snapin が $\alpha_{1 \mathrm{~A}}$ 受容体 の相互作用分子であり，この受容体の活性化により，

“ $\alpha_{1 \mathrm{~A}}$ 受容体 -Snapin-TRPC6 チャネル” 複合体を形成 して $\mathrm{Ca}^{2+}$ 流入を引き起こすという，新しい受容体作 動性 $\mathrm{Ca}^{2+}$ 流入機構を明らかにした.

\section{はじめに}

細胞内 $\mathrm{Ca}^{2+}$ 濃度 $\left(\left[\mathrm{Ca}^{2+}\right]_{\mathrm{i}}\right)$ の上昇は, 受容体の活 性化や細胞膜の脱分極など様々な刺激によって誘発さ れ, 筋収縮, 内 - 外分泌, 細胞増殖, 分化誘導など, 多様な生体反応を調節する最も重要な生理反応の一つ である.

$\mathrm{G}$ タンパク共役型受容体, 中でも, Gq タンパク共 役型受容体の活性化により, 細胞膜が脱分極すること なく $\left[\mathrm{Ca}^{2+}\right]_{\mathrm{i}}$ の上昇が惹起されることは良く知られて いる.このような $\left[\mathrm{Ca}^{2+}\right]_{\mathrm{i}}$ の上昇は, 細胞内 $\mathrm{Ca}^{2+}$ ス トアからの $\mathrm{Ca}^{2+}$ 遊離と, 細胞外からの $\mathrm{Ca}^{2+}$ 流入との 2 つからなっている. 受容体の刺激直後には, 受容体 の活性化により産生された $\mathrm{IP}_{3}$ が, 細胞内 $\mathrm{Ca}^{2+}$ スト ア膜上の $\mathrm{IP}_{3}$ 受容体を活性化することにより，ストア から $\mathrm{Ca}^{2+}$ が遊離される。このストアからの $\mathrm{Ca}^{2+}$ 遊離
に続いて起こる, 細胞外からの $\mathrm{Ca}^{2+}$ 流入には, 2 つの 経路があると考えられている，枯渴した「空の（empty)」ストアからのシグナルを受けて活性化されるス トア作動性 $\mathrm{Ca}^{2+}$ チャネル (Store-operated calcium channel, SOCC）と，ストアを介さず，より直接的に 受容体から活性化を受ける受容体作動性 $\mathrm{Ca}^{2+}$ チャネ ル (Receptor-operated calcium channel, ROCC) であ る(1-6). 現在も様々な阻害薬を用いて SOCC と ROCC を区別する試みがなされているが，この $\mathrm{Ca}^{2+}$ 流入のメカニズムについては多くの議論があり，まだ 完全に解明されたとはいえない. 特に, ROCC の分子 実体や受容体による活性化のメカニズムについては, まだ部分的にしか解明されていないのが現状である (7-9) (図 1 参照).

私たちは，代表的な Gq タンパク共役型受容体であ る $\alpha_{1}$ アドレナリン受容体のうち, 最も $\left[\mathrm{Ca}^{2+}\right]_{\mathrm{i}}$ 上昇 が大きい $\alpha_{1 \mathrm{~A}}$ サブタイプに着目し $(10,11)$ 研究を行な ってきた。そして， $\alpha_{1 \mathrm{~A}}$ 受容体には $\mathrm{C}$ 末端のアミノ 酸配列のみが異なるスプライスアイソフォームが複数 存在し, これらのアイソフォームが異なる $\left[\mathrm{Ca}^{2+}\right]_{\mathrm{i}}$ 反 応を示すことを報告した(12)。 そこで, さらに $\alpha_{1 \mathrm{~A}}$ 受容体作動性 $\mathrm{Ca}^{2+}$ 流入機構の分子メカニズムの解明 を目的として研究を行なった。

\section{1. $\alpha_{1 \mathrm{~A}}$ 受容体の相互作用分子としての Snapin および TRPC6 チャネルの関与}

私たちは, 受容体作動性 $\mathrm{Ca}^{2+}$ 流入機構には未知の 相互作用分子が関与しているのではないかと考えた (図 1 参照)。そこで, 代表的な $\mathrm{Gq}$ タンパク共役型受 容体として $\alpha_{1 \mathrm{~A}}$ 受容体を選び, これを baitとして, ヒト脳 cDNA ライブラリーを yeast two-hybrid 法によ りスクリーニングした。 その結果, $\alpha_{1 \mathrm{~A}}$ 受容体の相

キーワード： $\alpha_{1 \mathrm{~A}}$ アドレナリン受容体, Snapin, TRPC6 チャネル, 受容体作動性 $\mathrm{Ca}^{2+}$ 流入

福井大学医学部生命情報医科学講座薬理学領域（率910-1193 福井県吉田郡永平寺町松岡下合月 23-3)

e-mail: fumikos@u-fukui.ac.jp 原稿受領日 : 2008 年 2 月 1 日, 第 23 回日本薬理学会学術奨励賞受賞講演総説

Title: Roles of Snapin in $\alpha_{1 \mathrm{~A}}$-adrenoceptor-induced calcium influx through TRPC6 channels. Author: Fumiko Suzuki 


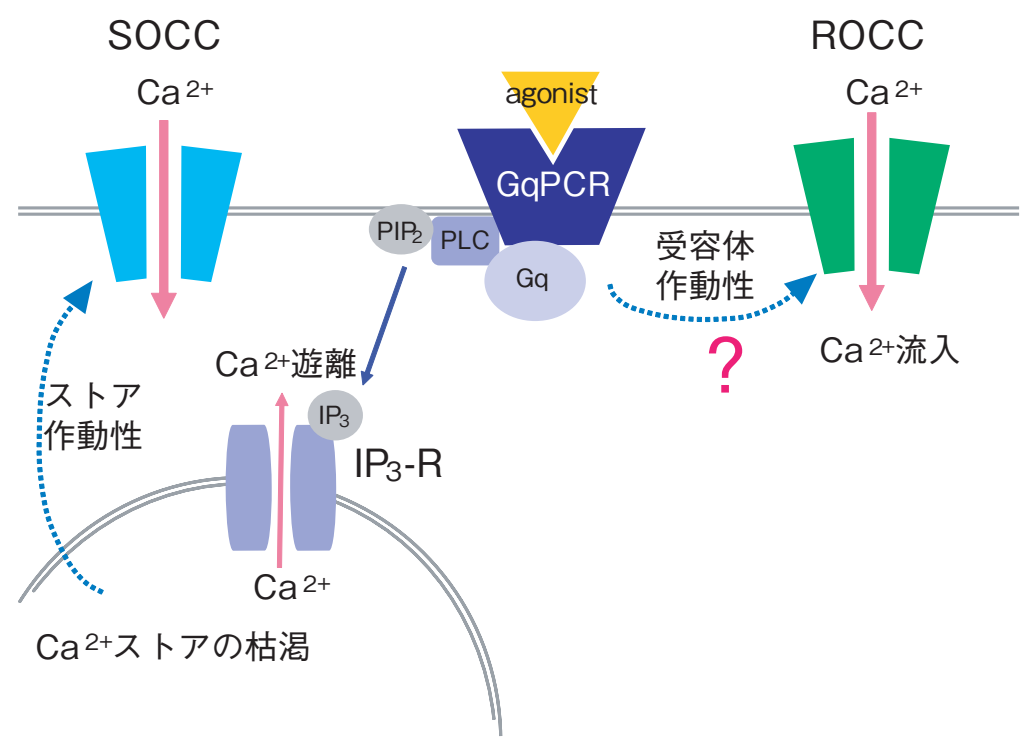

図 1 ストア作動性・受容体作動性 $\mathrm{Ca}^{2+}$ 流入機構の分子メカニズム

Gq タンパク共役型受容体 (GqPCR) の刺激直後には, 受容体の活性化により産生された $\mathrm{P}_{3}$ が細胞内 $\mathrm{Ca}^{2+}$ ストア膜上の $\mathrm{IP}_{3}$ 受容体 $\left(\mathrm{IP}_{3}-\mathrm{R}\right)$ を活性化することにより, ストアから $\mathrm{Ca}^{2+} か ゙$ 游離される。 これに続き, 枯渴したストアからのシグナルを受けて活性化されるのがストア作動 性 $\mathrm{Ca}^{2+}$ チャネル (SOCC) であり流入である。一方, ストアを介さず, 受容体から直接的に活性化されるものを受容体作動性 $\mathrm{Ca}^{2+}$ チャネル (ROCC) および流入という.

互作用分子として Snapin を同定した(13)。Snapin は SNARE 複合体と相互作用する分子として報告されて いるが(14-16), 私たちは初めて Gq タンパク共役型受 容体と相互作用することを明らかにした。

次に, Snapin と $\alpha_{1 \mathrm{~A}}$ 受容体が直接結合することを, in vitroで合成した各タンパク，およびラット脳ホモ ジネートを用いた免疫沈降実験により明らかにした。

また， $\alpha_{1 \mathrm{~A}}$ 受容体の活性化による $\mathrm{Ca}^{2+}$ 流入への関与 が示唆されてきたTRPC6 チャネルについても (17, 18）同様に免疫沈降実験を行ったところ，TRPC6 チャ ネルもSnapin に直接結合した。これらの結果から, Snapin は $\alpha_{1 \mathrm{~A}}$ 受容体と TRPC6 チャネルをリンクさせ る介在分子であると考えられた (13).

さらに, これら 3 分子間の結合が受容体の活性化に よって影響を受けるかどうか検討した。実験には, $\alpha_{1 \mathrm{~A}}$ 受容体とSnapin を共発現したラット副腎髄質細 胞由来である $\mathrm{PC} 12$ 細胞を用いた。 その結果, $\alpha_{1 \mathrm{~A}}$ 受 容体の活性化により “ $\alpha_{1 \mathrm{~A}}$ 受容体 -Snapin”および “Snapin-TRPC6 チャネル”のどちらの分子間も著しく 結合を増強し，言い換えれば “ $\alpha_{1 \mathrm{~A}}$ 受容体-SnapinTRPC6 チャネル”複合体が形成されることを明らか にした(13)。また，受容体の活性化により増強される この結合は， $\alpha_{1}$ 受容体拮抗薬で抑制されたことから， 受容体の活性状態に依存する変化であることが示唆さ れた。

\section{2. $\alpha_{1 \mathrm{~A}}$ 受容体作動性 $\mathbf{C a}^{2+}$ 流入における Snapin と TRPC6 チャネルの関与}

先に述べたように，TRPC6チャネルは， $\alpha_{1 \mathrm{~A}}$ 受容 体作動性の $\mathrm{Ca}^{2+}$ 流入に関与するチャネルの重要な候 補である。また， $\alpha_{1 \mathrm{~A}}$ 受容体の活性化により“ $\alpha_{1 \mathrm{~A}}$ 受容体-Snapin-TRPC6 チャネル” 複合体が形成された ことから，この受容体を刺激した際の $\left[\mathrm{Ca}^{2+}\right]_{\mathrm{i}}$ 上昇が Snapinによって影響を受けることが予測された。こ のため, Snapinの発現レベルと, この受容体の活性 化による $\left[\mathrm{Ca}^{2+}\right]_{\mathrm{i}}$ 上昇を検討した。 よく知られている ように， $\alpha_{1 \mathrm{~A}}$ 受容体の活性化により $\left[\mathrm{Ca}^{2+}\right]_{\mathrm{i}}$ は二相 性に上昇した。受容体刺激直後のストアからの $\mathrm{Ca}^{2+}$ 遊離による $\left[\mathrm{Ca}^{2+}\right]_{\mathrm{i}}$ の上昇は, Snapin の発現レベルに 影響を受けなかったが，それに続いて起こる細胞外か らの持続的な $\mathrm{Ca}^{2+}$ 流入は, Snapinの過剩発現細胞で は著しく増大したのに対し, 内在性の Snapinをノッ クダウンした細胞では抑制されるなど, Snapinの発 現レベルとょく相関していた。ささに， $\alpha_{1 \mathrm{~A}}$ 受容体 $\mathrm{C}$ 末端の Snapin 結合部位の変異体を用いた場合には, 野生型の $\alpha_{1 \mathrm{~A}}$ 受容体に比べて持続的 $\mathrm{Ca}^{2+}$ 流入が有意 に減少した。これらの結果から， $\alpha_{1 \mathrm{~A}}$ 受容体と Snapin の結合が持続的 $\mathrm{Ca}^{2+}$ 流入に必要であると考え られた(13).

次に, Snapinの発現によって増大した $\mathrm{Ca}^{2+}$ 流入が, ストア作動性か受容体作動性かを明らかにするために, 
A

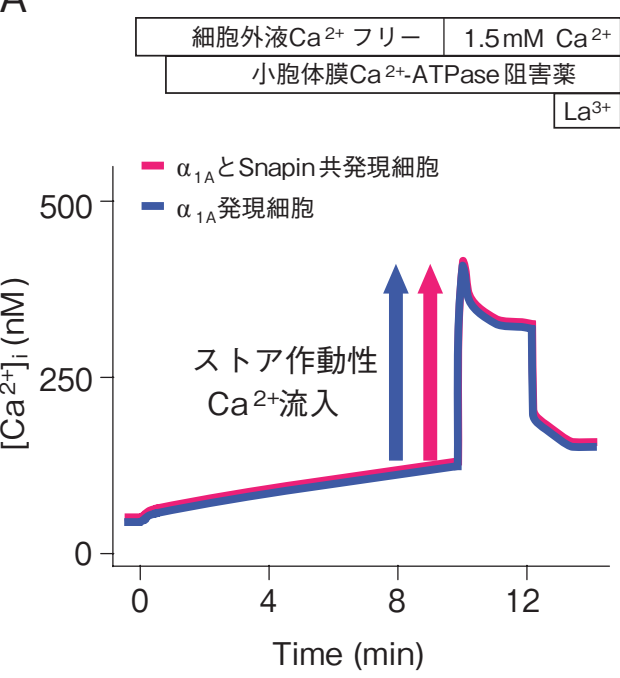

B

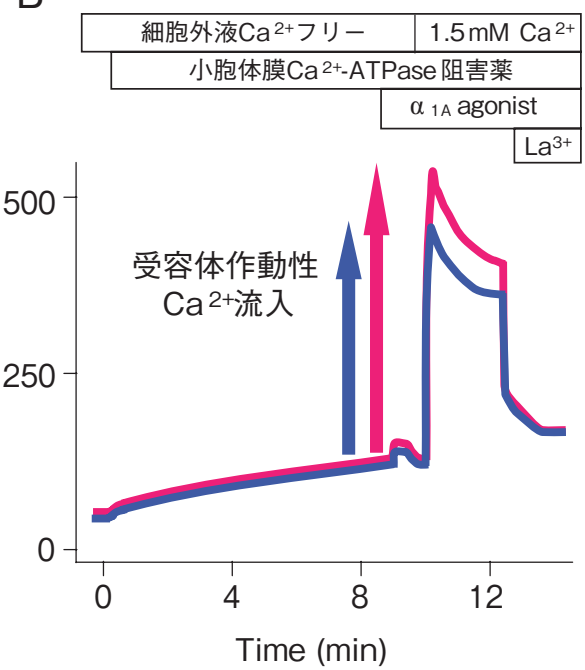

図 2 ストア作動性・受容体作動性 $\mathrm{Ca}^{2+}$ 流入と Snapin の関与（模式図）

SOCC を介する $\mathrm{Ca}^{2+}+$ 流入は， $\alpha_{17}$ 受容体のみトランスフェクトした細胞（青線）と， $\alpha_{11}$ 受容体とSnapin を共発現した細胞（赤線）の間 で有意差がなかった (A)。これに対して, $\mathrm{Ca}^{2+}$ 再添加 1 分前に $\alpha_{1 A}$ 受容体を刺激した場合の流入量は, 共発現細胞では有意に増加した (B)。(詳 細は本文参照. )

刺激前

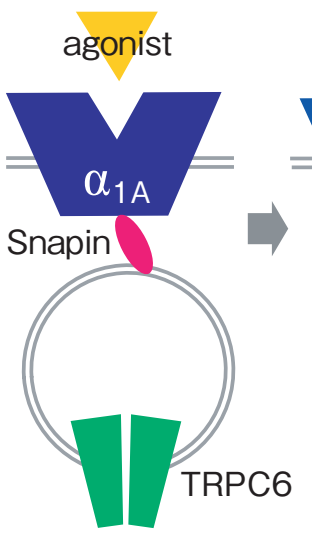

図 3 Snapin による $\alpha_{1 \mathrm{~A}}$ アドレナリン受容体作動性 $\mathrm{Ca}^{2+}$ 流入の分子メカニズム
刺激後
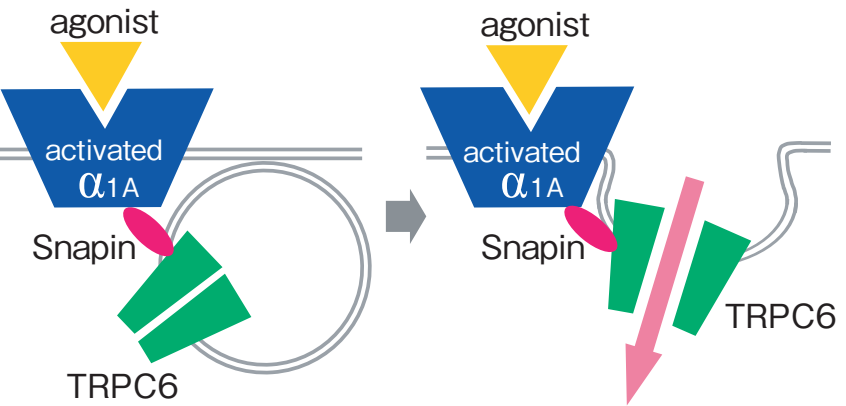

Ca $2+$ 流入
以下のような実験を行なった． $\mathrm{Ca}^{2+}$ を除いた細胞外液 中で，小胞体膜 $\mathrm{Ca}^{2+}$-ATPase 阻害薬である $\mathrm{DBHQ}$ に よりストア内の $\mathrm{Ca}^{2+}$ を枯渴させた後, 細胞外液に $\mathrm{Ca}^{2+}$ を再添加し, この時の $\left[\mathrm{Ca}^{2+}\right]_{\mathrm{i}}$ 上昇を調べた. $\mathrm{Ca}^{2+}$ 再 添加時に観察される $\mathrm{Ca}^{2+}$ 流入は, その時点での細胞 膜上のチャネルの活性化状態を反映している。 DBHQ 処置後の $\mathrm{Ca}^{2+}$ 流入はストアの枯渴のみにより活性化 された SOCC を介するものと考えられるが，これは Snapinの発現レベルには影響を受けなかったことか ら，SOCCを介する $\mathrm{Ca}^{2+}$ 流入には Snapin は関与しな いと考えられた。一方, 細胞外液に $\mathrm{Ca}^{2+}$ を再添加す る直前に $\alpha_{1 \mathrm{~A}}$ 受容体を刺激した際の $\mathrm{Ca}^{2+}$ 流入は, $\mathrm{DBHQ}$ 処置のみの場合に比べて有意に増加した。こ
の際の $\mathrm{Ca}^{2+}$ 流入は, $\mathrm{SOCC}$ と, $\alpha_{1 \mathrm{~A}}$ 受容体刺激によ り活性化された ROCC とを介する流入の和であると 考えられる. Snapinを過剩発現した細胞では, この ROCC を介する流入が，内在性の Snapin のみの細胞 に比べて有意に大きいことから，Snapin はストア作 動性にではなく， $\alpha_{1 \mathrm{~A}}$ 受容体作動性 $\mathrm{Ca}^{2+}$ 流入に特異 的に関与していると考えられた（図 2 参照).

また，このような持続的 $\mathrm{Ca}^{2+}$ 流入は，電位依存性 $\mathrm{Ca}^{2+}$ チャネル阻害薬である nifedipine, $\omega$-conotoxin GVIA， $\omega$-agatoxin TK では抑制されず，2-APB， SK\&F96365，および $\mathrm{La}^{3+} よ り$ 抑制された。後者 3 阻 害薬に感受性なのは TRPC6 サブタイプであることか ら, 先の免疫沈降の結果と考え合わせると, $\alpha_{1 \mathrm{~A}}$ 受 
容体作動性 $\mathrm{Ca}^{2+}$ 流入の経路には TRPC6 チャネルが関 与していることが強く示唆された(13).

\section{3. $\alpha_{1 \mathrm{~A}}$ 受容体の活性化による Snapin と TRPC6 の細胞内局在の変化}

TRPC チャネルを介する $\mathrm{Ca}^{2+}$ 流入が促進されるため には，TRPCチャネルが細胞膜表面に insert されるこ とが重要である $(19,20) ． \quad \alpha_{1 \mathrm{~A}}$ 受容体の活性化により “ $\alpha_{1 \mathrm{~A}}$ 受容体 -Snapin-TRPC6 チャネル” 複合体が形成 されたことに加えて， $\alpha_{1 \mathrm{~A}}$ 受容体は常時細胞膜に局 在することから，私たちは, Snapin や TRPC6 チャネ ルがこの受容体の活性化により細胞膜近傍に移行する のではないかと考え, これらの分子の細胞内局在を検 討した，実験に用いた野生型の PC12 細胞は, Snapin と TRPC6 チャネルを内在性に発現しているが， $\alpha_{1 \mathrm{~A}}$ 受容体は発現していない。この細胞においては, 内在 性の Snapin は細胞内に一様に分布していた。一方, この細胞に $\alpha_{1 \mathrm{~A}}$ 受容体をトランスフェクトすると, 細胞膜近傍に局在するSnapin が増加した. さらに, この共発現細胞において $\alpha_{1 \mathrm{~A}}$ 受容体を刺激すると, Snapin が更に細胞膜近傍に移行する像が観察された (13).

また，細胞の表面タンパクをビオチン化することに より細胞膜表面の TRPC6 チャネルを半定量したとこ ろ, $\alpha_{1 \mathrm{~A}}$ 受容体の活性化に伴い細胞膜表面の TRPC6 チャネルは増加した。これらの結果から， $\alpha_{1 \mathrm{~A}}$ 受容 体が活性化されると細胞膜上の TRPC6 チャネル数が 増加し, このチャネルを介した $\mathrm{Ca}^{2+}$ 流入が増大する と考えられた(13).

\section{4. $\alpha_{1 \mathrm{~A}}$ 受容体作動性 $\mathbf{C a}^{2+}$ 流入機構}

以上の結果を基に，次のような $\alpha_{1 \mathrm{~A}}$ 受容体作動性 $\mathrm{Ca}^{2+}$ 流入機構を考えた (図 3 参照).

$\alpha_{1 \mathrm{~A}}$ 受容体は常時細胞膜に局在するが, Snapin は 非刺激時には細胞内に一様に分布している。 $\alpha_{1 \mathrm{~A}}$ 受 容体が活性化されると“Snapin と $\alpha_{1 \mathrm{~A}}$ 受容体”が結 合しやすくなり, Snapinは細胞膜近傍へ移行する. またTRPC6 チャネルは, 非刺激時にはその大部分が 細胞内に分布しているが， $\alpha_{1 \mathrm{~A}}$ 受容体の活性化によ り “Snapin-TRPC6 チャネル”間の結合が著しく増強し, 細胞膜表面へ移行する。 その結果, 細胞膜表面に存在 する TRPC6 チャネル数が著しく増加し，このチャネ ルを介する $\mathrm{Ca}^{2+}$ 流入が増大する。これら一連の機序は, 細胞内 $\mathrm{Ca}^{2+}$ ストアの枯渇により引き起こされるスト ア作動の $\mathrm{Ca}^{2+}$ 流入とは独立した, 受容体作動性の $\mathrm{Ca}^{2+}$ 流入機構であり, このメカニズムによって $\alpha_{1 \mathrm{~A}}$ 受容
体作動性の $\mathrm{Ca}^{2+}$ 流入が起きると考えられた.

\section{おわりに}

$\alpha_{1 \mathrm{~A}}$ アドレナリン受容体と相互作用する分子とし て Snapin を同定し, Snapin が “ $\alpha_{1 \mathrm{~A}}$ 受容体 -SnapinTRPC6 チャネル” 複合体を形成する要の分子である ことを明らかにした，さらにこの複合体形成を介して $\mathrm{Ca}^{2+}$ 流入が惹起されるという, 新しい受容体作動性 $\mathrm{Ca}^{2+}$ 流入機構を提唱した。 また本研究は, TRPC6 チ ヤネルが $\alpha_{1 \mathrm{~A}}$ 受容体作動性 $\mathrm{Ca}^{2+}$ チャネルとして機能 することも明らかにした。

今後は, 本研究により明らかになった $\alpha_{1 \mathrm{~A}}$ 受容体 作動性 $\mathrm{Ca}^{2+}$ 流入の増大機構について, TRPC6 チャネ ルの細胞膜表面への移行のメカニズムおよび SNARE 複合体の関与などの点について, さらに詳細な検討を 行ないその全容を解明していきたい。また, Snapin による $\mathrm{Ca}^{2+}$ 流入増大機構が生体内で担う役割と意義, および疾患との関連についても明らかにしたいと考え ている.

謝辞 : 本研究の遂行にあたり, 多大なるご指導を賜りまし た福井大学医学部薬理学領域の村松郁延教授, 森島繁講師, ならびに教室員の方々に厚く御礼申し上げます。また，日 本薬理学会学術奖励賞選考委員ならびに関係者の先生方に 深謝致します。

\section{文献}

1) Gibson A, et al. Trends Pharmacol Sci. 1998;19:266-269.

2) Li SW, et al. Trends Pharmacol Sci. 2002;23:63-70.

3) McFadzean I, et al. Br J Pharmacol. 2002;135:1-13.

4) Yuan JP, et al. Nat Cell Biol. 2007;9:636-645.

5) Lewis RS. Nature. 2007;446:284-287.

6) Hewavitharana T, et al. Cell Calcium. 2007;42:173-182.

7) Dietrich A, et al. Handb Exp Pharmacol. 2007;179:125-141.

8) Kiselyov K, et al. Handb Exp Pharmacol. 2007;179:559-574.

9) Spassova MA, et al. Biochim Biophys Acta. 2004;1742:9-20.

10) Zhong H, et al. J Neurochem. 1999;72:2388-2396.

11) Theroux TL, et al. Mol Pharmacol. 1996;50:1376-1387.

12) Suzuki F, et al. Br J Pharmacol. 2000;129:1569-1576.

13) Suzuki F. J Biol Chem. 2007;282:29563-29573.

14) Ilardi JM, et al. Nat Neurosci. 1999;2:119-124.

15) Chheda MG, et al. Nat Cell Biol. 2001;3:331-338.

16) Tian JH, et al. J Neurosci. 2005;25:10546-10555.

17) Inoue R, et al. Circ Res. 2001;88:325-332.

18) Thebault S, et al. J Cell Physiol. 2005;204:320-328.

19) Cayouette S, et al. J Biol Chem. 2004;279:7241-7246.

20) Trebak M, et al. Handb Exp Pharmacol. 2007;179:593-614.

著者プロフィール（写真は 3 月号 $13 \mathrm{~A}$ に掲載 $)$

鈴木 史子 (すずき ふみこ)

福井大学 医学部 薬理学領域, 助教, 博士 (医学)

$\diamond 1996$ 年福井医科大学 (現福井大学) 医学部 薬理学領域, 助 手, 現在に至る. ○研究テーマ：アドレナリン受容体と細胞内 カルシウムシグナル. 趣味 : 研究と家庭の両立の模索. 